\title{
Interleukin-2 Liposome
}

National Cancer Institute

\section{Source}

National Cancer Institute. Interleukin-2 Liposome. NCI Thesaurus. Code C2373.

A formulation in which liposomes are loaded with the cytokine interleukin-2 (IL-2). By activating cytotoxic T-lymphocytes, such as lymphokine-activated killer cells, and increasing levels of the cytotoxic cytokines interferon-gamma (IFN-gamma) and transforming growth factor-beta (T GF-beta), IL-2 may exhibit antitumoral activity. Liposomal formulations of IL-2 may promote entry of the cytokine into target tumor cells and may be used as an immunoadjuvant in cancer vaccine therapy. ( $\mathrm{NClO4})$ 